\title{
THE ANALYSIS OF GIVING REWARDS BY THE TEACHER IN LEARNING MATHEMATICS GRADE 5 STUDENTS OF SD NEGERI 184 PEKANBARU
}

\author{
Sri Yunengsih ${ }^{1}$, Syahrilfuddin ${ }^{2}$ \\ 1,2 Universitas Riau, Pekanbaru, Indonesia \\ ${ }^{1}$ sriyunengsih180814@gmail.com, ${ }^{2}$ syahrilfuddin.karim@yahoo.com
}

\begin{abstract}
This study aims to find out and describe the rewards given by teachers in learning mathematics of fifth grade students of SD Negeri 184 Pekanbaru. This research was conducted in grade 5 SD Negeri 184 Pekanbaru on Jl. Putri Tujuh Pekanbaru. The activity was carried out in odd semester 2019/2020 which held on 11 November 2019 - 6 December 2019. The type of research was qualitative research. Based on the results of this study concluded that the provision of rewards by teachers in grade 5 SDN 184 Pekanbaru been implemented well in learning mathematics. These forms of rewards given in the form of verbal and non-verbal, prize, and value rewards. The impact of giving rewards given by teachers to students in learning mathematics has an impact on student motivation. Students are enthusiastic in participating in learning and students self-confidence is increasing.
\end{abstract}

Keywords: reward, learning mathematics, elementary school

\section{ANALISIS PEMBERIAN REWARD OLEH GURU DALAM PEMBELAJARAN MATEMATIKA SISWA KELAS V SD NEGERI 184 PEKANBARU}

\begin{abstract}
ABSTRAK
Penelitian ini bertujuan untuk mengetahui dan mendeskripsikan pemberian reward oleh guru dalam pembelajaran matematika siswa kelas V SD Negeri 184 Pekanbaru. Penelitian ini dilaksanakan di kelas V SD Negeri 184 Pekanbaru di Jl. Putri Tujuh Pekanbaru. Kegiatan dilakukan pada semester ganjil 2019/2020 yakni pada tanggal 11 November 2019 - 6 Desember 2019. Jenis penelitian ini adalah penelitian kualitatif. Berdasarkan hasil penelitian dapat disimpulkan bahwa pemberian reward oleh guru dikelas V SD Negeri 184 Pekanbaru sudah dilaksanakan dengan baik pada pembelajaran matematika di kelas V. Bentuk reward yang diberikan berupa reward verbal dan non verbal, reward hadiah dan reward nilai. Dampak dari pemberian reward yang diberikan guru kepada siswa dalam pembelajaran matematika berdampak pada motivasi belajar siswa. Siswa bersemangat dalam mengikuti pembelajaran dan rasa percaya diri siswa manjadi meningkat.
\end{abstract}

Kata Kunci: reward, pembelajaran matematika, sekolah dasar

\begin{tabular}{|c|c|c|}
\hline Submitted & Accepted & Published \\
\hline 29 Mei 2020 & 03 Juli 2020 & 23 Juli 2020 \\
\hline
\end{tabular}

\begin{tabular}{|l|c|r|}
\hline Citation & $:$ & $\begin{array}{r}\text { Yunengsih, S., \& Syahrilfuddin. (2020). The Analysis of Giving Rewards by the Teacher in Learning Mathematics Grade } \\
5 \text { Students of SD Negeri 184 Pekanbaru. Jurnal PAJAR (Pendidikan dan Pengajaran), 4(4), 715-723. DOI : } \\
\text { http://dx.doi.org/10.33578/pjr.v4i2.8029. }\end{array}$ \\
\hline
\end{tabular}

\section{PENDAHULUAN}

Pelajaran matematika di sekolah menjadi mata pelajaran pokok yang wajib diikuti siswa. Pelajaran matematika perlu diberikan kepada semua peserta didik mulai dari sekolah dasar untuk membekali siswa dengan kemampuan mengembangkan dan melatih cara berfikir dan berhitung dalam pemecahan suatu masalah. Terciptanya pembelajaran matematika yang baik dijenjang sekolah dasar dapat terlaksana dengan menggunakan pembelajaran agar siswa lebih aktif.

$$
\text { Afidah dan Khairunisa (2015:2) }
$$
menyatakan bahwa bagi dunia pengetahuan, matematika berperan sebagai bahasa simbolik yang merupakan sarana ilmiah untuk mengembangkan cara berfikir logis. Matematika di sekolah mempunyai peran yang sangat penting 
dalam upaya meningkakan kualitas berfikir peserta didik. Kualitas berfikir peserta didik yang baik memudahkan peserta didik untuk dapat menyelesaikan masalah yang ada. Matematika menjadi ilmu yang sangat penting dan berguna dalam kehidupan (Setyono, 2007:1). Dalam kehidupan banyak aktivitas kita yang berhubungan dengan matematika, seperti halnya mengukur bangunan, menghitung uang, mencari nomor rumah dan sebagainya, sebab itu ilmu matematika sangat penting dipelajari. Pembelajaran matematika sangat baik di ajarkan dari jejang pendidikan sekolah dasar hingga perguruan tinggi. Matematika merupakan mata pelajaran penting, dikarenakan kegunaan dalam kehidupan seharihari, tetapi juga manfaatnya dalam mempelajari ilmu-ilmu lain (Suryana, 2009). Matematika memiliki manfaat dalam pembentukan daya berfikir siswa hal ini akan menjadikan siswa dapat dengan mudah mempelajari ilmu lainnya.

Matematika dianggap sebagai pelajaran yang menakutkan karena matematika membuat peserta didik merasa tidak nyaman (Setyono, 2007). Selama ini siswa menganggap bahwa matematika itu sebagai mata pelajaran yang sulit karena berhubungan dengan angka dan hitung. Hal ini mendorong kecenderungan siswa untuk bersikap malas dan tidak tertarik dengan pelajaran matematika, akibatnya siswa menghindari pelajaran matematika. Perkembangan pelajaran matematika di masa yang akan datang dapat terganggu jika hal ini terus berlanjut. Sundayana (2015) mengatakan matematika merupakan pelajaran yang sukar dipahami, hal yang menyebabkan keadaan tersebut terjadi dikarenakan siswa kurang memahami pembelajaran dan tidak menyukai belajar matematika, dampaknya motivasi belajar matematika menurun dan berpengaruh terhadap hasil belajar matematikanya.

Untuk mengatasi masalah tersebut dapat digunakan strategi pembelajan yang menyenangkan, salah satu cara yang dapat diciptakan untuk membuat proses pembelajaran yang menyenangkan yaitu reward. Reward adalah suatu cara yang dapat dijadikan alat motivasi bagi siswa untuk belajar lebih baik (Shoimin, 2014).
Pemberian reward sebagai salah satu cara yang dapat dilakukan untuk mengatasi permasalah yang terjadi dalam pembelajaran matematika. matematika seringkali menjadi pelajaran yang tidak disukai oleh siswa karena berbagai hal. Pemberian reward bisa dilakukan untuk membuat anak lebih tertarik dalam belajar matematika.

Reward dapat mendorong dan mendukung berjalannya pembelajaran. Pemberian reward dapat berbentuk materi, barang, angka, nilai, dan pujian yang di diberikan secara verbal maupun non verbal (Sardiman, 2011). Bentuk pemberian reward dapat berupa pujian, Pemberian reward membuat siswa termotivasi dalam pembelajaran dan membuat hasil belajar matematika menjadi lebih baik.

Siswa yang memiliki keinginan dan semangat yang tinggi dalam belajar berkemungkinan untuk dapat memperoleh hasil belajar matematika yang memuaskan, hal ini berarti semakin tinggi keinginan dan semangat siswa belajar dengan usaha yang dilakukan, maka akan semakin tinggi kesempatan memperoleh hasil belajar matematika yang memuaskan. Pemberian reward yang dilakukan oleh guru sebagai upaya dalam memotivasi siswa dalam belajar, pemberian reward juga dapat mewujudkan hasil belajar yang lebih baik, adanya pemberian reward mendorong siswa untuk belajar sehingga hasil belajar meningkat.

Berdasarkan permasalahan tersebut, peneliti menganggap penting melakukan suatu penelitian melalui penelitian kualitatif deskriptif. Rumusan penelitian dalam penelitian ini adalah Berdasarkan latar belakang yang telah dikemukakan maka penelitian ini merumuskan masalah dalam penelitian ini adalah "bagaimana pemberian reward oleh guru dalam pembelajaran matematika siswa kelas V SD Negeri 184 Pekanbaru". Tujuan penelitian ini adalah mengetahui reward yang diberikan oleh guru dalam pembelajaran matematika siswa kelas $\mathrm{V}$ SD Negeri 184 Pekanbaru dan mendeskripsikan pemberian reward oleh guru dalam pembelajaran matematika siswa kelas V SD Negeri 184 Pekanbaru. 


\section{KAJIAN TEORETIS}

Reward merupakan salah satu cara yang dapat dijadikan alat motivasi bagi siswa sehingga hasil belajar siswa menjadi dapat lebih baik (Shoimin, 2014:157). Reward merupakan sesuatu yang diberikan oleh seseorang kepada orang lain sebagai bentuk penghargaan, kenang-kenangan ataupun cendramata (Djamarah, 2011:161). Reward merupakan suatu cara untuk menggerakan atau membangkitkan motivasi belajar anak (Hamalik, 2014:73). Reward atau hadiah merupakan sesuatu yang mampu menumbuhkan motivasi dalam kegiatan belajar di sekolah (Sardiman, 2011:96). Bentuk reward dapat berupa berbagai hal yang dapat membuat siswa merasa senang dan bahagia. Bentuk Reward dapat berupa penghargaan, pujian, bintang, nilai, angka ataupun berupa barang yang disukai oleh siswa. Bentuk Reward bertujuan untuk membuat siswa lebih bersemangat dalam mengikuti pembelajaran dan membuat hasil belajarnya akan meningkat. Menurut Mulyasa (2008:78) ada tiga tujuan pemberian reward yaitu Meningkatkan perhatian siswa terhadap pembelajaran, Merangsang dan meningkatkan motivasi belajar dan meningkatkan

\section{METODE PENELITIAN}

Penelitian ini akan dilakukan di kelas V SD Negeri 184 Pekanbaru di Jl. Putri Tujuh Pekanbaru. Kegiatan dilakukan pada semester ganjil 2019/2020 yakni pada tanggal 11 November 2019 - 6 Desember 2019. Metode penelitian yang digunakan peneliti ialah kualitatif yang bersifat deskriptif. penelitian ini bertujuan untuk mendeskripsikan pemberian reward oleh guru dalam pembelajaran matematika dimana hasil penelitian yang diperoleh disajikan berupa katakata. Dalam penelitian ini peneliti berusaha mendeskripsikan peristiwa dan kejadian yang menjadi pusat perhatian peneliti dengan apa adanya sesuai fakta di lapangan dan tidak memberikan perlakuan khusus terhadap peristiwa tersebut. Metode penelitian kualitatif adalah metode penelitian yang berlandaskan pada filsafat postpositivisme, digunakan untuk meneliti pada kondisi objek yang alamiah (Sugiyono, 2017). kegiatan belajar dan membina perilaku yang produktif.

Belajar didefenisikan sebagai tindakan dan perilaku yang dialami langsung oleh siswa (Dimyati \& Mudjiono, 2009:9). Siswa menjadi penentu terjadi atau tidaknya suatu proses belajar. Belajar merupakan kegiatan yang pokok dalam penyelengaraan di jejang pendidikan, tujuan pendidikan dapat terwujud apabila proses belajar siswa terlaksana dengan baik (Jihad \& Haris, 2013:1). ). Pembelajaran matematika sangat penting dipelajari karena dalam kehidupan banyak berhubungan dengan matematika. melihat jam, menukar uang ataupun mencari nomor rumah, itu semua berhubungan dengan matematika. Matematika di sekolah bertujuan untuk dapat meningkatkan cara berfikir peserta didik. Sardiman (2011:96) reward atau hadiah merupakan sesuatu hal yang dapat menumbuhkan motivasi dalam kegiatan belajar di sekolah. Pemberian reward menciptakan pembelajaran yang menyenangkan dan siswa lebih termotivasi dalam belajar matematika dengan termotivasinya siswa tersebut maka pemberian reward sangat berpengaruh dalam pelaksanaannya.

Subjek penelitian ini adalah guru kelas V SD Negeri 184 Pekanbaru. Subjek penelitian ini berjumlah empat orang guru.

Observasi adalah pengamatan dan pencatatan sistematik terhadap gejala yang tampak pada objek penelitian (Asmani , 2011:40). Bentuk observasi yang digunakan dalam penelitian ini adalah observasi nonpartisipan maksudnya peneliti tidak ikut aktif dalam proses pembelajaran yang berlangsung di kelas. Peneliti hanya mengamati interaksi yang terjadi antara guru dan siswa selama kegiatan proses berlangsung. Peneliti masuk ke ruang kelas untuk melakukan observasi tetapi tidak ikut terlibat dalam proses pembelajartan. Peneliti hanya mengamati interaksi yang terjadi antara guru dan siswa selama kegiatan proses pembelajaran berlangsung. Observasi digunakan dengan tujuan untuk mendapatkan gambaran dengan jelas tentang pemberian reward oleh guru kepada siswa kelas $\mathrm{V}$ 
SD Negeri 184 Pekanbaru. Obervasi dilakukan pada tanggal 11 November - 6 Desember 2019. Lembar observasi yang digunakan peneliti dalam penelitian ini berdasarkan indikator reward pada tabel 1.

Tabel 1. Indikator-Indikator Pemberian Reward

\begin{tabular}{ll}
\hline NO INDIKATOR & \multicolumn{1}{c}{ DESKRIPSI } \\
\hline 1. Reward Verbal dan Non Verbal & $\begin{array}{l}\text { Pemberian pujian akan memupuk suasana yang } \\
\text { menyenangkan dan mempertinggi gairah belajar }\end{array}$ \\
& serta sekaligus akan membangkitkan harga diri \\
& siswa sehingga prestasi belajar siswa ikut \\
& meningkat. Pujian disini adalah pujian verbal dan \\
& non verbal. Misalnya ucapan bagus, hebat, pintar, \\
& tepuk tangan, senyum, jempol tangan dan menepuk \\
& pundak. \\
& Reward berbentuk hadiah disini adalah pemberian \\
& berupa barang . Yaitu hadiah yang terdiri dari alat- \\
& alat keperluan sekolah, seperti pensil, penggaris, \\
& buku dan lain-lain. Pemberian berbentuk barang \\
& seperti makanan dan lainnya. \\
& Angka sebagai simbol kegiatan belajar, angka yang \\
& dimaksud adalah nilai tambahan bagi siswa yang \\
& mengerjakan tugas dengan baik \\
\hline Reward Nilai/Angka &
\end{tabular}

Wawancara adalah teknik yang digunakan untuk pengumpulan data apabila peneliti ingin mengetahui hal-hal dari responden secara yang lebih mendalam (Sugiyono,2017:231). Satori dan Aan (2014:129) menyatakan bahwa wawancara adalah suatu teknik pengumpulan data untuk mendapatkan informasi yang digali dari sumber data langsung melalui percakapan atau tanya jawab. Dalam penelitian ini teknik wawancara yang dilakukan adalah wawancara semi standar (semistandardized interview). Wawancara semi standar membuat garis besar pokok pembicaraan namun dalam pelaksanaan interviewer mengajukan pertanyaan secara bebas pokok-pokok pertanyaan tidak perlu secara berurutan, peilihan kata-kata tidak baku tetapi dimodifikasi sesuai dengan kondisi dan situasi.

Metode dokumentasi dilakukan dengan cara menyelidiki benda-benda tertulis seperti buku, majalah, notulen rapat, catatan harian, dan sebagainya (Arikunto, 2013:201). Dalam penelitian ini, peneliti mengambil dokumen berupa foto dan video kegiatan pembelajaran. Melalui studi dokumentasi ini, peneliti memperoleh informasi dari macam-macam sumeber tertulis atau dokumen yang ada pada informan. Selanjutnya dianalisis dengan menggunakan teknik analisis data kualitatif Miles dan Huberman yang terdiri dari tiga tahapan reduksi data, tahap penyajian data dan tahap penarikan kesimpulan / verifikasi.

Analisis data dalam penelitian kualitatif, dilakukan saat pengumpulan data berlangsung, dan setelah pengumpulan data pada periode tertentu. Dalam penelitian ini, peneliti menggunakan metode analisis data model Miles \& Huberman 1984 (dalam Sugiyono, 2017:338).

Berikut merupakan gambaran model analisis data Miles dan Huberman (Interaktive Model) tersebut: 


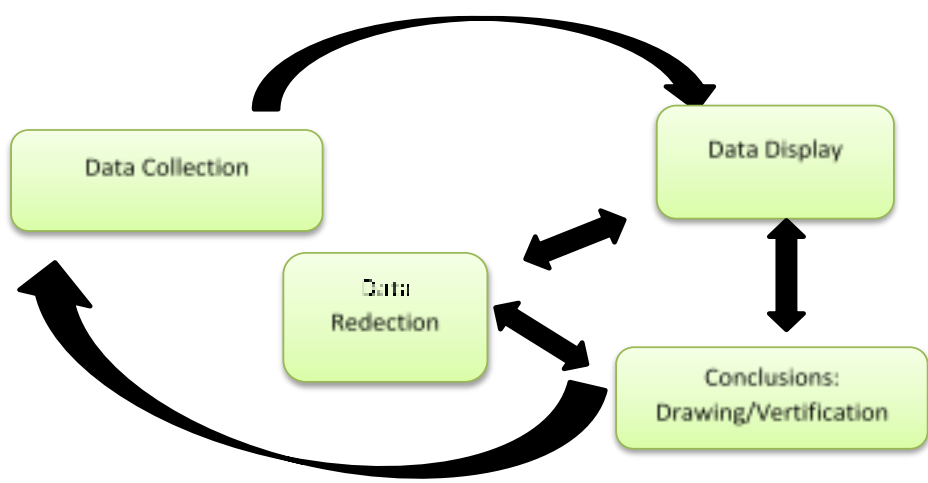

Gambar 1. komponen dalam Analisis Data (Interactiv Model) Sumber : (Sugiyono, 2017:338)

Analisis data menurut Miles dan Huberman 1984 (dalam Sugiyono, 2017:338) dilakukan dengan:

\section{1) Reduksi Data}

Mereduksi data berarti merangkum, memilih hal-hal pokok, memfokuskan pada halhak yang penting, serta dicari tema dan polanya. Dengan demikian data yang telah diroduksi akan memberikan gambaran yang lebih jelas dan mempermudah peneliti untuk melakukan pengumpulan data selanjutnya dan mencarinya apabila diperlukan.

2) Data Display (Penyajian Data)

Setelah data direduksi maka hal yang selanjutnya yang akan dilakukan adalah mendisplay data. Menurut Sugiyono (2017:341) dalam penelitian kualitatif, penyajian data bisa dilakukan dalam bentuk uraian singkat, bagan, hubungan antara kategori, flowchart, dan sejenisnya". Melalui penyajian data ini, maka data lebih terorganisasi, tersusun dalam pola yang saling berhubungan, sehingga akan lebih mudah untuk dipahami.

3) Penarikan Kesimpulan dan Verifikasi

Kegiatan ini dimaksudkan untuk mencari data yang dikumpulkan dengan mencari hubungan, persamaan atau perbedaan. Penarikan kesimpulan dilakukan dengan jalan membandingkan kesesuaian pernyataan dan subjek penelitian tersebut. Verifikasi dimaksudkan agar penelitian tentang kesesuaian data dengan maksud yang terkandung dalam konsep-konsep dasar dala penelitian tersebut lebih tepat dan objektif.

\section{Keabsahan Data}

Pengujian keabsahan data dalam penelitian kualitatif dilakukan diantaranya dengan uji kreabilitas data (Sugiyono, 2017:366) Langkah yang ditempuh untuk memperoleh kreabilitas data (Sugiyono, 2017:369) adalah sebagai berikut: 1) Memperpanjang pengamatan, (melakukan pengamatan sebanyak 7-10 kali pertemuan); 2) Meningkatkan ketekunan, dalam penelitian peneliti mengangkat pemberian reward oleh guru dalam pembelajaran matematika kelas V SD Negeri 184 Pekanbaru; 3) Triangulasi, peneliti menyimpulkan dari hasil observasi yang dilakukan di kelas V SD Negeri 184 Pekanbaru; 4) Analisis kasus negatif, peneliti menganalisa pemberian reward oleh guru di kelas V SD Negeri 184 Pekanbaru. 


\section{HASIL DAN PEMBAHASAN Hasil Penelitian}

Berdasarkan analisis data yang diperoleh dari triangulasi pengumpulan data observasi, wawancara dan dokumentasi yang telah dilakukan peneliti, adanya pemberian reward dalam Proses pembelajaran matematika di kelas V SD Negeri 184 Pekanbaru sudah dilaksanakan dengan baik. Memperhatikan dan menelaah hasil observasi, waawancara dan dokumentasi dengan para narasumber tentang temuan hasil penelitian yang berkaitan dengan pemberian reward oleh guru dalam pembelajaran matematika siswa kelas $\mathrm{V}$ SDN 184 Pekanbaru.

Guru memberikan reward dalam bentuk verbal maupun non verbal untuk siswa yang menunjukkan sikap baik. Siswa yang menunjukkan sikap baik seperti dapat menjawab pertanyaan dan siswa yang berani mengeluarkan pendapat dalam menjawab soal yang diberikan. Wawancara yang dilakukan juga memberikan penjelasan bahwa guru memberikan reward berupa verbal maupun non verbal dalam pembelajaran matematika. Reward yang diberikan berupa reward verbal seperti hebat, betul, bagus, baik, iya, mantap, benar dan pandai. Reward non verbal seperti tepuk tangan, tersenyum dan acungkan jempol. Guru memberikan reward dalam bentuk pemberian hadiah untuk siswa yang dapat menjawab pertanyaan yang diberikan dalam pembelajaran matematika. Wawancara yang dilakukan juga memberikan penjelaskan bahwa guru memberikan reward berupa pemberian hadiah. Reward hadiah yang diberikan seperti kue, biskuit dan pena. Guru memberikan reward berupa penambahan nilai, untuk siswa yang dapat menunujjan sikap baik seperti dapat menyelesaikan soal yang diberikan. Wawancara yang dilakukan juga memberikan penjelasan bahwa guru memberikan reward berupa penambahan nilai.

Dampak dari pemberian reward yang diberikan guru kepada siswa dalam pembelajaran matematika berdampak pada motivasi belajar siswa. Siswa bersemangat dalam mengikuti pembelajaran dan rasa percaya diri siswa manjadi meningkat. Siswa yang mendapatkan reward menjadi termotivasi untuk belajar dengan baik dan siswa lebih menyukai pembelajaran matematika karena siswa berani untuk menjawab pertanyaan tanpa rasa takut.

Berdasarkan hasil observasi, respon siswa ketika menerima reward menunjukkan bahwa siswa senang diberikan reward. Siswa terlihat sangat bersemangat dan antusias ketika guru memberikan pujian baik secara verbal maupun non verbal dan guru memberikan reward berupa nilai. Siswa yang belum mendapatkan reward tampak ikut memberikan apresiasi untuk siswa yang mendapatkan reward dan terlihat berusaha untuk mendapatkan reward juga dengan cara menjawab pertanyaan yang diiberikan oleh guru. siswa menjadi lebih termotivasi dengan guru memberikan reward. Hasil observasi yang dilakukan peneliti diperkuat dengan hasil wawancara yang dilakukan.

Berdasarkan hasil wawancara dengan guru, respon siswa ketika menerima reward secara verbal maupun non verbal dan reward nilai, hasil wawancara sebagai berikut :

\section{"tanggapan atau respon siswa ketika menerima reward sangat sennag dan bahagia. Dengan adanya pemberian reward menambah motivasi siswa untuk pembelajaran matematika" (Kardinal/6- 12-2019).}

Berdasarkan triangulasi sumber yang dilakukan dapat disimpulkan bahwa respon dan reaksi siswa setelah menerima reward terlihat senang, termotivasi dan antusias dalam mengikuti pembelajaran. Siswa berantusias dalam mengerjakan soal latihan yang diberikan oleh guru. siswa menjadi berani untuk menuliskan jawaban ke depan kelas.

\section{Analisis Respon Siswa Setelah Menerima Reward Kelas VD}

Berdasarkan hasil observasi, respon siswa ketika menerima reward menunjukkan siswa senang dan siswa lain lebih termotivasi untuk dapat menjawab pertanyaan dari guru. siswa terlihat bersemangat untuk menjawab pertanyaan dari guru dan rasa percaya diri siswa muncul 
sehingga siswa dengan berani untuk menjawab pertanyaan dari guru. siswa juga melompat dan bersorak ketika guru memberikan reward karena bahagia. Hasil observasi yang dilakukan peneliti diperkuat dengan hasil wawancara yang dilakukan.

Berdasarkan hasil wawancara dengan guru, respon siswa ketika menerima reward secara verbal maupun non verbal, hasil wawancara sebagai berikut :

"Sangat senang dan sangat bahagia yang pasti mereka senang dan mereka merasa pekerjaan mereka betul-betul dihargai tidak hanya disuruh dibuat saja, tapi juga ada mendapat penghargaan otomatis mereka menjadi bahagia senang dan mereka juga bangga dengan reward yang mereka terima". (hk/6-12-2019).

Berdasarkan triangulasi sumber yang dilakukan dapat disimpulkan bahwa respon dan reaksi siswa setelah menerima reward berbentuk verbal maupun non verbal, reward berupa hadiah dan nilai terlihat siswa senang, bahagia dan siswa lain juga termotivasi untuk melakukan hal yang sama yaitu dapat menjawab pertanyaan dari guru tanpa rasa takut. Siswa lebih berantusias dalam menjawab setiap pertanyaan yang diberikan oleh guru.

\section{Analisis Respon Siswa Setelah Menerima Reward Kelas VA}

Berdasarkan hasil observasi, respon siswa ketika menerima reward menunjukkan bahwa siswa tersenyum senang dan siswa lain juga ikut memberikan apresiasi. Siswa termotivasi dan lebih berantusias dalam mengikuti pembelajaran. Dengan adanya guru memberikan reward siswa menjadi bersemangat dalam mengikuti pembelajaran. Hasil observasi yang dilakukan peneliti diperkuat dengan hasil wawancara yang dilakukan.

Berdasarkan hasil wawancara dengan guru, respon siswa ketika menerima reward secara verbal maupun non verbal, hasil wawancara sebagai berikut :

\begin{abstract}
"sangat senang sekali kalau bisa setiap mengajar kita kasih reward. Reward bukan hanya berupa materi, reward bisa berupa pujian. anak itu kalau dipuji sudah senang apalagi oleh guru wali kelasnya lagi dan motivasi belajar anak meningkat”. (Ruslan/6-12-2019)
\end{abstract}

Berdasarkan triangulasi sumber yang dilakukan dapat disimpulkan bahwa respon siswa setelah menerima reward terlihat senang sehingga siswa jadi bersemangat dan antusias siswa meningkat dalam mengikuti pembelajaran matematika

\section{Analisis Respon Siswa Setelah Menerima Reward Kelas VC}

Berdasarkan hasil observasi yang, respon siswa ketika menerima reward menunjukkan bahwa siswa lebih bersemangat dan berantusias dalam menjawab pertanyaan yang diberikan oleh guru. siswa menjadi lebih percaya diri untuk menjawab pertanyaan. Hasil observasi yang dilakukan peneliti diperkuat dengan hasil wawancara yang dilakukan.

Berdasarkan hasil wawancara dengan guru, respon siswa ketika menerima reward secara verbal maupun non verbal, hasil wawancara sebagai berikut :

"Mereka malah bersemangat, bahkan mereka ingin gurunya bertanya dan melakukan kuis setiap hari. mereka merasa memiliki kemampuan sehinga ingin kegiatan tanya jawab rutin dilakukan". (ej/6-12-209).

Berdasarkan triangulasi sumber yang dilakukan dapat disimpulkan bahwa respon siswa setelah menerima reward verbal maupun non verbal, reward hadiah dan reward nilai. terlihat senang sehingga siswa jadi bersemangat dan siswa termotivasi dalam mengikuti pembelajaran matematika. 


\section{Pembahasan}

Bentuk reward yang diberikan oleh guru bervariasi mulai dari bentuk reward pujian secara verbal maupun non verbal, reward hadiah dan reward penambahan nilai. Ini sesuai dengan apa yang dikatakan oleh Sardiman (2011) Pemberian reward dapat berbentuk materi, barang, angka, nilai, dan pujian yang di diberikan secara verbal maupun non verbal.Ini juga didukung oleh pendapat Suyuti (Prasetyo Atik Heru, 2019) Pemberian reward dapat berupa kata-kata pujian, senyuman, tepuk tanggan, dan bahkan bentuk materi dan sesuatu yang menyenangkan bagi siswa.

Istilah reward yang di ketahui oleh guru merupakan sebuah penghargaan atas hasil kerja siswa, baik secara tertulis maupun secara lisan yang diberikan oleh guru berupa pujian, hadiah maupun nilai. Reward diberikan agar anak merasa senang karena pekerjaannya bagus. Hal ini sejalan dengan teori Purwanto (Wijaya intan apri dkk, 2019) menjelaskan reward adalah sebagai alat untuk mendidik anak-anak supaya anak merasa senang karena perbuatannya atau pekerjaannya mendapat penghargaan.

Penghargaan yang diberikan guru kepada siswa sangat penting agar siswa lebih antusias dalam belajar. Penghargaan tidak hanya berbentuk materi saja tetapi bisa berupa pujian, baik pujian secara verbal maupun non verbal. Reward merupakan alat pendidikan untuk memotivasi siswa agar lebih bersemangat dalam belajar dan melakukan sesuatu hal yang baik.

Dalam pelaksanaan pembelajaran matematika guru sering memberikan pujian kepada siswa yang telah berani mengeluarkan pendapat. Dengan adanya pemberian reward

\section{SIMPULAN DAN REKOMENDASI}

Berdasarkan analisis data dapat disimpulkan bahwa pemberian reward oleh guru di SD Negeri 184 Pekanbaru sudah dilaksanakan dengan baik pada pembelajaran matematika di kelas V. Bentuk reward yang diberikan guru dalam pembelajaran matematika di kelas V SD Negeri 184 Pekanbaru berupa reward verbal seperti hebat, betul, bagus, baik ,iya, mantap, benar dan pandai. menjadikan proses pembelajaran matematika lebih menyenangkan. Pemberian reward pujian secara verbal maupun non verbal yang diberikan oleh guru membuat siswa senang dan siswa merasa pekerjaannya di hargai oleh guru. Pemberian reward membuat siswa termotivasi dan bersemangat mengikuti pembelajaran matematika. Hal ini senada dengan Kusyairy \& Sulkipli (2018) Reward merupakan salah-satu cara yang dapat dilakukan sebagai pendorong, penyemangat dan motivasi dalam proses pembelajaran agar peserta didik lebih meningkatkan prestasi hasil belajar.

Dampak dari pemberian reward yang diberikan guru kepada siswa dalam pembelajaran matematika berdampak pada motivasi belajar siswa. Siswa bersemangat dalam mengikuti pembelajaran dan rasa percaya diri siswa manjadi meningkat. Siswa menjadi berani mengeluarkan pendapat dan berani bersuara. Pemberian reward memberikan pengaruh terhadap siswa untuk melakukan perbuatan yang positif dan bersikap progresif terhadap pembelajaran matematika.

Hal ini sejalan dengan penelitian sebelumnya Prasetyo Atik Heru (2019) Dampak pemberian reward adalah memicu siswa untuk berkompetisi secara adil dan sehat serta memotivasi belajar siswa dapat tumbuh dan berkembang secara maksimal, memberikan pengaruh yang cukup besar terhadap jiwa anak didik untuk melakukan perbuatan yang positif dan bersikap progresif terhadap pembelajaran matematika, menjadi pendorong bagi anak didik lainnya terhadap siswa yang teladan, baik dalam tingkah laku, sopan santun, bagus dalam nilai akademik, sehingga akan memberi contoh yang baik bagi siswa lain dan memotivasinya.

Reward non verbal seperti tepuk tangan, tersenyum dan acungkan jempol. Sangat bagus diberikan dan sering dilakukan oleh guru. Reward hadiah seperti kue, biskuit dan pena dilakukan sebagai variasi dalam pemberian reward. Reward nilai berupa pemberian nilai tambahan. Pemberian reward nilai sangat mudah diberikan dan siswa menjadi bersemangat dalam belajar. 
Peneliti mengharapkan hasil penelitian ini dapat memberikan kontribusi dalam dunia pendidikan khususnya pendidikan Sekolah Dasar maka peneliti mengemukakan saran sebagai berikut guru sebagai teladan bagi para siswa, hendaknya selalu mendorong, dan memotivasi siswa dengan cara yang tepat, memberikan reward untuk menumbuhkan motivasi belajar siswa hendaknya ditunjang dengan inovasi baru dalam pembelajaran matematika agar tercapai prestasi yang diharapkan. Reward berupa verbal dan non

\section{DAFTAR PUSTAKA}

Afidah, \& Khairunisa. (2015). Matematika Dasar. Jakarta: PT Rajagrafindo Perdasa.

Asmani. (2011). Pendidikan Internalisasi Pendidikan Karakter di Sekolah. Yogyakarta: Diva Pres.

Dimyati, \& Mudjiono. (2009). Belajar dan Pembelajaran. Jakarta: PT Rineka Cipta.

Djamarah, S. B. (2011). PsikologiBelajar. Jakarta: Rineka Cipta.

Hamalik, O. (2014). Proses Belajar Mengajar. Jakarta: Bumi Aksara.

Jihad, A. \& Abdulah H. (2013). Evaluasi Pembelajaran. Yogyakarta: Multi Pressindo.

Kusyairy,U. \& Sulkili. (2018). Meningkatkan Hasil Belajar Peserta Didik Melalui Pemberian Reward and Punishment. Jurnal Pendidikan Fisika. 6(2).(online).http://jounal.uin.alauddin.ac.i d/index.php/pendidikan

fisika/article/view/55955 204 (diakses 6 Mei 2019)

Moleong, L. J. (2014). Metodologi Penelitian Kualitatif. Bandung: PT Remaja Rosdakarya.

Mulyasa, E. (2008). Menjadi Guru Profesional Menciptakan Pembelajaran Kreatif dan Menyenangkan. Bandung: PT. Remaja Rosdakarya.

Prasetyo A. H. dkk. 2019. Analisis Dampak Pemberian Reward dan Punishment Dalam Proses Pembelajaran Matematika. Journal pedagogik dan Pembelajaran, 2 (3)(online) verbal sangat penting dan mudah dilakukan oleh guru. reward hadiah dan nilai dilakukan sebagai variasi dalam pemberian reward. Siswa hendaknya berlatih dan giat belajar, serta mengembangkan potensi diri agar dapat meraih prestasi belajar yang maksimal dan selalu termotivasi dalam proses belajar mengajar. Kepada peneliti yang akan melanjutkan penelitian ini diharapkan untuk dapat mengembangkan penelitian tentang faktor-faktor yang mempengaruhi motivasi belajar siswa lainnya.

.https://ejounal.indiksha.ac.id/index.php /jp2/article/view/19332

Sardiman. (2011). Interaksi dan Motivasi Belajar Mengajar. Jakarta: Rajawali Pers.

Satori D. dan Aan K. (2014). Metode Penelitian Kualitatif. Bandung: Alfabeta

Setyono (2007). Mathemagics. Jakarta: PT Gramedia Pustaka Utama.

Shoimin, A. (2014). 68 Model Pembelajaran Inovatif dalam Kurukulum 2013. Yogyakarta: Ar-Ruzz Media.

Sugiyono. (2017). Metode Penelitian Pendidikan. Bandung: Alfabeta, cv.

Sundayana, R. (2015). Media dan Alat Peraga dalam Pembelajaran Matematika. Bandung: Alfabeta cv.

Suryana, A. (2009). Bermain dengan matematika. Jakarta: Anggota IKAPI.

Wijaya dkk. (2019) Analisis Pemberian Reward dan Punisment Pada Sikap Disiplin SD N 01 Sokaraja Tengah. Jurnal Educatio FKIP UNMA. 5 (2) (online). https://ejournal.unma.ac.id/index.php/educ atio/article/view/17 (diakses 5 februari 2020) 